\title{
Downregulation of long-form prolactin receptor mRNA during prolactin-induced luteal regression
}

\author{
Jennifer M Bowen ${ }^{1,3}$, Carlos M Telleria ${ }^{4}$, Roberto Towns ${ }^{2,3}$ and P Landis Keyes ${ }^{1,3}$ \\ Departments of ${ }^{1}$ Physiology and ${ }^{2}$ Internal Medicine, and ${ }^{3}$ Reproductive Sciences Program, University of Michigan, Ann Arbor, Michigan \\ 48109-0622, USA and ${ }^{4}$ Department of Physiology and Biophysics, University of Illinois at Chicago, Chicago, Illinois 60612-7342, USA \\ (Correspondence should be addressed to P Landis Keyes, Department of Physiology, University of Michigan, 7635 Medical Sciences II Building, \\ Ann Arbor, Michigan 48109-0622, USA; Email: plkey@umich.edu) \\ (J M Bowen is now at Department of Pharmacology and Clinical Pharmacology, Faculty of Medical and Health Sciences, University of Auckland, \\ Private Bag 92019, Auckland, New Zealand) \\ (C M Telleria is now at Larlac-Conicet, Casilla de Correo 855, 5500 Mendoza, Argentina)
}

\begin{abstract}
Objective: Prolactin is capable of both trophic and lytic actions in rat corpora lutea. In corpora lutea responding to a trophic prolactin signal, the long form of the prolactin receptor is the dominant form and is upregulated by prolactin. We investigated whether mRNA for the short form of the prolactin receptor was dominant in corpora lutea responding to a lytic prolactin signal, and whether the relative concentrations of the mRNAs for both forms of the prolactin receptor were changed during this response.

Design and methods: Immature rats were ovulated by injection of 5 IU equine chorionic gonadotrophin and $5 \mathrm{IU}$ human chorionic gonadotrophin, and were hypophysectomized shortly after ovulation. Nine days after hypophysectomy, rats were injected with prolactin $(500 \mu \mathrm{g} /$ day $)$ or vehicle for $24(n=6$, $n=6)$ or $72 \mathrm{~h}(n=13, n=5)$. Total RNA was isolated from corpora lutea and mRNA for both types of prolactin receptor were analyzed by semiquantitative RT-PCR using the ribosomal protein S16 as the internal control.

Results: The intensities of the long- and short-form prolactin receptor signals were normalized to the S16 internal control and expressed as relative densitometric units. The normalized values at $24 \mathrm{~h}$ for prolactin-treated vs vehicle-treated rats were $0.23 \pm 0.05$ vs $0.49 \pm 0.15(P>0.05)$ for the short form and $4.04 \pm 0.8$ vs $4.23 \pm 0.6(P>0.05)$ for the long form. The values for $72 \mathrm{~h}$ were $0.30 \pm 0.05 \mathrm{vs}$ $0.24 \pm 0.05(P>0.05)$ for the short form and $2.76 \pm 0.4$ vs $5.53 \pm 0.3(P<0.01)$ for the long form respectively.

Conclusion: The long form of the prolactin receptor is the dominant form at both time-points; however, the concentration of mRNA for this receptor isoform was specifically downregulated by prolactin treatment. Our results suggest that the short form of the prolactin receptor alone is unlikely to mediate the luteolytic action of prolactin, but that luteolytic events may be influenced via a change in the ratio of the two receptor isoforms.
\end{abstract}

European Journal of Endocrinology 143 285-292

\section{Introduction}

Administration of prolactin to hypophysectomized rats, after at least 3 days of hypophysectomy, results in regression of the corpora lutea; otherwise, in the absence of prolactin, these corpora lutea remain intact and steroidogenically active for an indefinite period (1-4). The luteolytic effects of prolactin include decreases in plasma $20 \alpha$-dihydroprogesterone, the predominant steroid secreted by corpora lutea of the hypophysectomized rat $(3,4)$, and luteal weight (5). These effects of prolactin following hypophysectomy contrast sharply with the luteotrophic effect of the hormone during pregnancy and pseudopregnancy. In the latter states, prolactin acts to maintain high progesterone secretion by the corpora lutea, by inhibiting conversion of progesterone to $20 \alpha$-dihydroprogesterone (6), and by maintaining luteal receptors for luteinizing hormone (7). Prolactin also acts in concert with oestradiol to increase protein synthesis in the corpus luteum $(8,9)$.

Both the luteolytic and the luteotrophic effects of prolactin are active events, presumably mediated through the prolactin receptor. In the rat, there are two forms of the prolactin receptor, derived from the same gene and with identical extracellular and transmembrane domains. The two forms have a common 
intracellular sequence of 27 amino acids, followed by a unique sequence of 331 amino acids for the 'long form' of the prolactin receptor, and a unique sequence of 31 amino acids for the 'short form' (10).

The two forms of the prolactin receptor may transmit different signals. The long form of the prolactin receptor is known to activate the transcription of milk protein genes (11-13) via the transcription factor STAT 5 (1416). In contrast, the short form of the prolactin receptor is unable to activate STAT 5 (14). The long form of the prolactin receptor is also known to activate the tyrosine kinase JAK2 (17-20), while the ability of the short form to signal through JAK2 is debated. While one report indicates that both forms of the prolactin receptor associate and activate JAK2, as well as activating the transcription factor STAT1 (20), another states that the short form is unable to activate JAK2 (21). The authors of this second report suggest that the primary role of the short form of the prolactin receptor is to act as a dominant negative by heterodimerizing with the long form of the receptor (21). However, the short form of the prolactin receptor has been shown to transmit a mitogenic signal in at least one cell type (13), indicating that it is a functional receptor. In addition, a tyrosine phosphorylated protein that associates specifically with the short form of the prolactin receptor has been identified in the corpus luteum $(22,23)$, suggesting that the short form of the prolactin receptor may have a specific signalling function in this tissue.

Telleria et al. (24) examined the expression of luteal prolactin receptor isoforms during pregnancy, when prolactin acts as a luteotrophin. They reported that mRNA for the long form of the prolactin receptor was predominant over mRNA for the short form. In addition, mRNA for the long form of the receptor was specifically increased by prolactin, while expression of mRNA for the short form was not altered (24). The luteotrophic action of prolactin in the rat is associated with increased DNA binding of several STAT proteins, specifically STATs $3,5 \mathrm{a}$ and $5 \mathrm{~b}(25,26)$. As the short form of the prolactin receptor is unable to activate STAT 5 (14), this suggests that the luteotrophic action of prolactin is mediated through the long form of the prolactin receptor. We have proposed that the ability of prolactin to carry out both luteolytic and luteotrophic actions may result from variations in the type of receptor present on the corpus luteum. Specifically, we have suggested that the short form of the prolactin receptor would be the dominant form present in corpora lutea responding luteolytically to prolactin, and that the short form of the prolactin receptor would be upregulated during this action of prolactin.

\section{Materials and methods}

\section{Animals}

Immature female Sprague-Dawley rats were obtained from Charles River (Portage, MI, USA). Rats received an s.c. injection of $5 \mathrm{IU}$ equine chorionic gonadotrophin at 29 days of age to induce follicular development, followed by an s.c. injection of $5 \mathrm{IU}$ human chorionic gonadotrophin $56 \mathrm{~h}$ later to induce ovulation and the development of corpora lutea. Following ovulation, the rats were hypophysectomized at 32 days of age by the vendor. All rats were provided with rat chow and $5 \%$ glucose in water ad libitum, and were supplemented with sliced oranges. Animal procedures were approved by the University Committee on the Use and Care of Animals at the University of Michigan.

\section{Experimental design}

Rats $(n=30)$ were divided into four groups. Treated rats $(n=19)$ received injections of ovine prolactin $(250$ $\mu \mathrm{g}$ in $0.2 \mathrm{ml}$ vehicle, s.c.) at 12 -h intervals (1000 and $2200 \mathrm{~h}$ ) on days 9-11 post-hypophysectomy, and were killed by decapitation $24 \mathrm{~h}(n=6)$ or $72 \mathrm{~h}(n=13)$ after the onset of prolactin treatment. Control rats $(n=11)$ were given injections of $0.2 \mathrm{ml}$ vehicle $(0.1 \%$ bovine serum albumin (BSA) and $0.03 \mathrm{~mol} / \mathrm{I} \mathrm{NaHCO}_{3}$ in $0.15 \mathrm{~mol} / \mathrm{l} \mathrm{NaCl}$, s.c.) and were also killed at $24(n=6)$ or $72(n=5) \mathrm{h}$ after the beginning of treatment. Trunk blood was collected from all rats, and plasma was obtained for later radioimmunoassay of $20 \alpha$-dihydroprogesterone. The ovaries were removed immediately and the corpora lutea dissected out and weighed as a group. The corpora lutea from each rat (eight to fifteen) were frozen in liquid nitrogen and stored at $-70{ }^{\circ} \mathrm{C}$ until later extraction of total RNA. The sella turcica was visually inspected in all rats for the presence of pituitary fragments and rats with incomplete hypophysectomy were removed from the experiment (reflected in the numbers given above).

\section{Hormones}

Ovine prolactin (NIDDK-oPRL, lot no. AFP10677C) was obtained from the National Institute of Diabetes and Digestive and Kidney Diseases of the NIH (Bethesda, MD, USA). The prolactin was diluted in $0.15 \mathrm{M} \mathrm{NaCl}, 0.03 \mathrm{M}$ $\mathrm{NaHCO}_{3}$ and $0.1 \%$ BSA to a final concentration of $1.25 \mathrm{mg} / \mathrm{ml}$ and $\mathrm{pH}$ of $8.2-8.6$. Diluted prolactin was stored at $4{ }^{\circ} \mathrm{C}$ and used within 1 week.

\section{Radioimmunoassay}

Plasma concentration of $20 \alpha$-dihydroprogesterone was determined by radioimmunoassay. After decapitation of the rats, trunk blood was collected into heparinized tubes and then centrifuged at $1740 \mathrm{~g}$ for $20 \mathrm{~min}$. The plasma was frozen in liquid nitrogen, and stored at $-20{ }^{\circ} \mathrm{C}$ until extracted and assayed for $20 \alpha-$ dihydroprogesterone according to the method previously described by Bender et al. (27). 


\section{RNA isolation and RT-PCR analysis}

Total RNA was extracted from homogenates of isolated corpora lutea using TRIZOL Reagent (phenol and guanidine isothiocyanate solution; LifeTechnologies Inc., Grand Island, NY, USA) and the protocol provided by the company. Each sample contained luteal tissue from one rat with the exception of the prolactin-treated group at $72 \mathrm{~h}$, for which each sample contained luteal tissue from two to three rats. Due to one poor round of RNA extraction, the total number of samples was decreased by one in each group, with the exception of the 72-h prolactin-treated animals. Detection of longand short-form prolactin receptor mRNAs was carried out by RT-PCR using three oligonucleotide primers described previously (24). Briefly, a sense strand oligonucleotide from the common extracellular domain coding region was combined with either of two primers corresponding to the first 23 nucleotides of the unique cytoplasmic sequence for the long form or short form of the receptor respectively. The predicted size of the PCR-amplified product was $279 \mathrm{bp}$ for both forms of the prolactin receptor. An additional pair of primers specific to the rat ribosomal protein S16 (5'TCCAAGGGTCCGCTGCAGTC-3' and 5'-CGTTCACCTT GATGAGCTCATT-3') were used in each reaction as an internal control. The predicted size of the PCR-amplified product for $\mathrm{S} 16$ was $100 \mathrm{bp}$. Three micrograms of total RNA were reverse transcribed at $42{ }^{\circ} \mathrm{C}$ using random hexamer primers (Pharmacia, Piscataway, NJ, USA) and Moloney murine leukaemia virus reverse transcriptase (LifeTechnologies Inc.) in a $20 \mu$ l reaction mixture. Reverse transcription was carried out in duplicate for each sample. The reaction mixtures for each sample were added to either a tube containing $50 \mathrm{pmol}$ each of the oligonucleotide primers for amplification of the short form of the prolactin receptor or a tube containing $50 \mathrm{pmol}$ each of the oligonucleotide primers for amplification of the long form of the prolactin receptor. Each tube also contained 16.5 pmol each of the oligonucleotide primers for amplification of S16. PCR was carried out using $\left[\alpha_{-}{ }^{32} \mathrm{P}\right]$ deoxy-CTP as previously described (24) for 25 cycles, with an annealing temperature of $65^{\circ} \mathrm{C}$. Under these conditions, amplification of prolactin receptor and $\mathrm{S} 16$ products from corpus luteum mRNA is in the exponential phase and the assay is linear with respect to the amount of input RNA. The kinetics of amplification are similar for cDNAs of the two forms of the prolactin receptor due to the similarity of the primer sets used and the identical size of the reaction products.

PCR reaction products were electrophoresed on $6 \%$ polyacrylamide non-denaturing gels. There was a total of four gels containing reaction products for both prolactin-treated and control groups as follows: longform prolactin receptor at $24 \mathrm{~h}$, long-form prolactin receptor at $72 \mathrm{~h}$, short-form prolactin receptor at $24 \mathrm{~h}$, and short-form prolactin receptor at $72 \mathrm{~h}$. Total RNA from the GGCL cell line, which does not contain the prolactin receptor (28), was reverse transcribed and submitted to PCR in parallel with the samples to be tested, as a negative control, and was run on each gel. Autoradiographic data were analyzed using a Molecular Dynamics PhosphorImager and ImageQuant version 3 software (Molecular Dynamics, Sunnyvale, CA, USA). The intensities of the long- and short-form prolactin receptor signals were normalized to the S16 internal control, and are expressed as relative densitometric units.

\section{Statistics}

Luteal weight and plasma 20 $\alpha$-dihydroprogesterone values were compared between groups using the Bonferroni multiple comparisons test. Plasma 20 $\alpha$ dihydroprogesterone values were log transformed prior to statistical analysis to normalize variance. Comparisons of densitometric values within a gel were made using Student's $t$-test.

\section{Results}

\section{Luteal weight}

Weight is expressed as mg/corpus luteum (mean \pm S.E.M.) and was $0.77 \pm 0.03 \mathrm{mg}$ for control rats at $24 \mathrm{~h}$ $(n=6), 0.57 \pm 0.04$ for prolactin-treated rats at $24 \mathrm{~h}$ $(n=6), 0.74 \pm 0.03$ for control rats at $72 \mathrm{~h}(n=5)$, and $0.38 \pm 0.03$ for prolactin-treated rats at $72 \mathrm{~h}$ ( $n=13$; Fig. 1). There was no difference in weight between the control groups at 24 and $72 \mathrm{~h}$ $(P>0.05)$. Luteal weight was significantly lower in the prolactin-treated groups at both time-points, when compared with the control groups $(P<0.05)$. In addition, luteal weight declined from 24 to $72 \mathrm{~h}$ after the onset of prolactin treatment $(P<0.05)$.

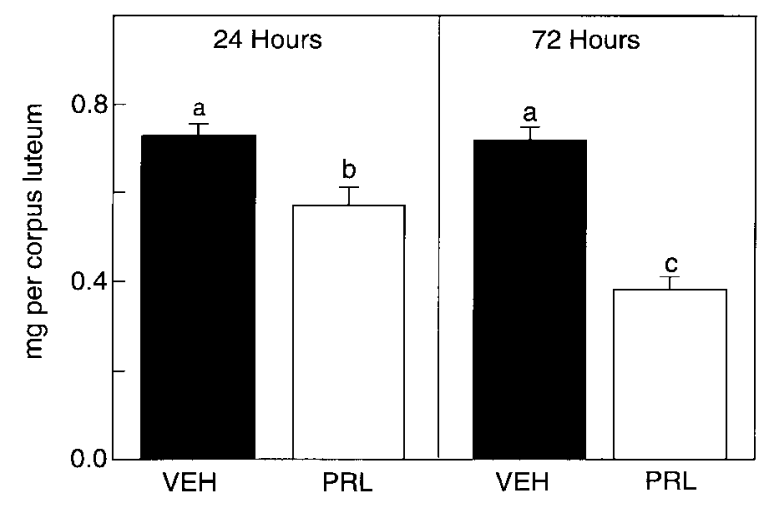

Figure 1 Luteal weight in $\mathrm{mg} /$ corpus luteum (mean \pm S.E.M.) for corpora lutea of rats injected with either vehicle (VEH; solid bars) or prolactin (PRL; open bars) and killed at 24 or $72 \mathrm{~h}$ after the onset of treatment. Different letters indicate significant differences at $P<0.05$. 


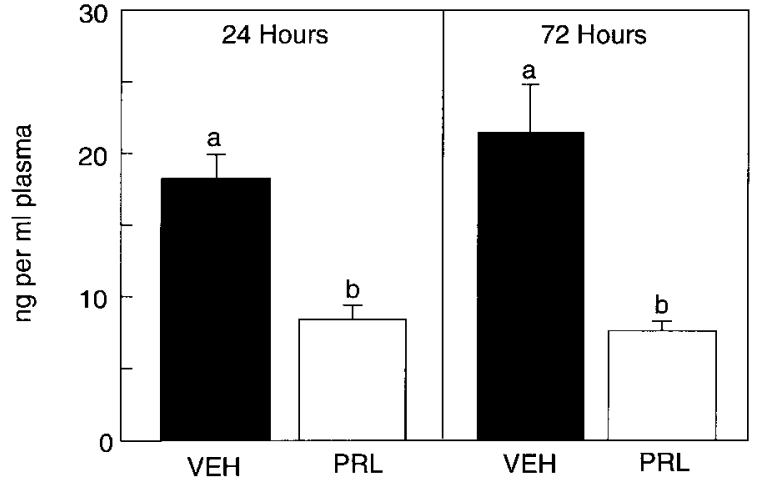

Figure 2 Plasma $20 \alpha$-dihydroprogesterone concentration in $\mathrm{ng} / \mathrm{ml}$ plasma (mean \pm S.E.M.) for rats injected with either vehicle (VEH; solid bars) or prolactin (PRL; open bars) and killed at 24 or $72 \mathrm{~h}$ after the onset of treatment. Different letters indicate significant differences at $P<0.05$.

\section{$20 \alpha$-Dihydroprogesterone}

Plasma concentration of $20 \alpha$-dihydroprogesterone is expressed as $\mathrm{ng} / \mathrm{ml}$ (mean \pm s.E.M.) and was $18.2 \pm 1.7$ for control rats at $24 \mathrm{~h}(n=6), 8.3 \pm 1.0$ for prolactintreated rats at $24 \mathrm{~h}(n=6), 22.0 \pm 3.4$ for control rats at $72 \mathrm{~h}(n=5)$, and $7.5 \pm 0.7$ for prolactin-treated rats at $72 \mathrm{~h}(n=13$; Fig. 2$)$. There were no significant differences between the two control groups or the two prolactin-treated groups $(P>0.05)$. However, plasma $20 \alpha$-dihydroprogesterone was significantly decreased in prolactin-treated groups when compared with control groups $(P<0.05)$.

\section{Prolactin receptor mRNA expression}

The abundance of mRNA for the long form of the prolactin receptor appeared to be greater than for the short form of the prolactin receptor following both $24 \mathrm{~h}$ (Fig. 3) and $72 \mathrm{~h} \mathrm{(Fig.} \mathrm{4)} \mathrm{of} \mathrm{prolactin} \mathrm{treatment.} \mathrm{Using}$ densitometry, the amount of RT-PCR product specific for the long and short forms of the receptor was quantified. The intensity of the signal for each sample was normalized to the intensity of the S16 signal for that sample, and the resulting value is expressed in relative densitometric units. At $24 \mathrm{~h}$ following the onset of prolactin treatment, the short form of the prolactin receptor was at $0.23 \pm 0.05$ units (mean \pm s.E.M.) for the prolactin-treated group $(n=5)$ and at $0.49 \pm 0.15$ units for the control group $(n=5$; Fig. 3$)$. These values were not significantly different $(P>0.05)$. At $72 \mathrm{~h}$ following prolactin, the short form of the prolactin receptor was at $0.30 \pm 0.05$ units for the prolactintreated group $(n=6)$ and at $0.24 \pm 0.05$ units for the control group ( $n=4$; Fig. 4). Again, these values were not different $(P>0.05)$. Although there were no significant differences in the amount of cDNA for the short form of the receptor between treatment groups, this may be due to the great variation in abundance of this mRNA among the samples. The mean value was lower in corpora lutea of prolactin-treated than of vehicle-treated rats at $24 \mathrm{~h}$, and greater in prolactintreated than in vehicle-treated at $72 \mathrm{~h}$, which does suggest an increase in the amount of mRNA for the short form of the prolactin receptor during this period of luteal regression.

For the long form of the prolactin receptor, values at $24 \mathrm{~h}$ following the onset of prolactin treatment were $4.04 \pm 0.8$ units for the prolactin-treated group $(n=5)$ and $4.23 \pm 0.6$ units for the control group $(n=5)$ and were not different $(P>0.05$; Fig. 3$)$. However, at $72 \mathrm{~h}$ following the onset of prolactin treatment, values for the long form of the prolactin receptor were $2.76 \pm 0.4$ units for the prolactin-treated group $(n=6)$ and $5.53 \pm 0.3$ units for the control group $(n=4)$ and these values were significantly different $(P<0.01$; Fig. 4). The data suggest that the abundance of mRNA for the long form of the prolactin receptor was essentially identical for corpora lutea of prolactintreated and vehicle-treated rats at $24 \mathrm{~h}$, but by $72 \mathrm{~h}$ after the onset of treatment the mRNA for the long form of the prolactin receptor was significantly decreased in corpora lutea of prolactin-treated rats. This indicates downregulation of mRNA for this form of the prolactin receptor during prolactin-induced luteal regression.

\section{Discussion}

The decreases in weight per corpus luteum and in steroid production, as indicated by a drop in plasma $20 \alpha$-dihydroprogesterone, indicate that prolactin treatment resulted in the expected regressive changes in the corpora lutea. These changes occurred as early as $24 \mathrm{~h}$ after the onset of prolactin treatment, following two injections of prolactin, and luteal weight continued to decline over the next $48 \mathrm{~h}$ of treatment. Analysis of mRNA expression of the long and short forms of the prolactin receptor revealed that the long form of the prolactin receptor was clearly the dominant form present in these corpora lutea at both these time-points. However, expression of mRNA for the long form of the prolactin receptor appeared to be downregulated by $72 \mathrm{~h}$ after the onset of prolactin treatment. The data also indicated a trend towards increased abundance of mRNA for the short form of the prolactin receptor at this 72-h time-point; however, this was not significant, probably due to the considerable variation in expression of mRNA for this form of the prolactin receptor. RT-PCR analysis was used to determine changes in prolactin receptor isoforms in this study due to low abundance of prolactin receptor in the rat ovary (29), and thus difficulties in quantifying this mRNA using Northern analysis.

Telleria et al. (24) have shown that the long form of the prolactin receptor is the most abundant form in the corpora lutea at all stages of pregnancy. Corpora lutea of pregnancy respond to prolactin with enhanced progesterone production and luteal development $(6,8)$, and at 


\section{Prolactin Receptor Long Form}

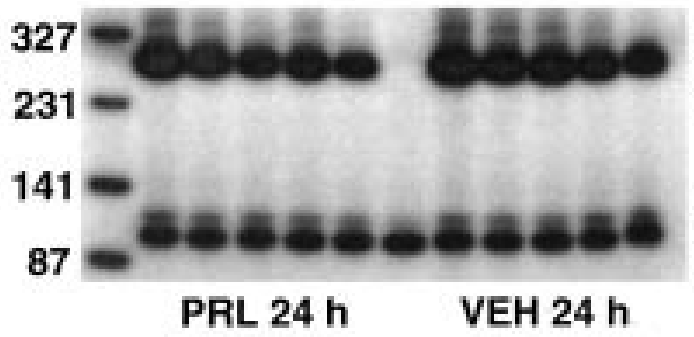

PRL-R

279

$\mathrm{S} 16$

100

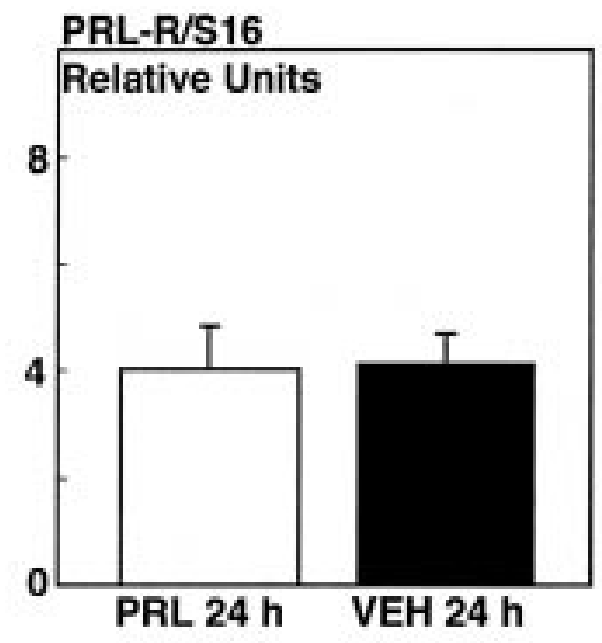

\section{Prolactin Receptor Short Form}

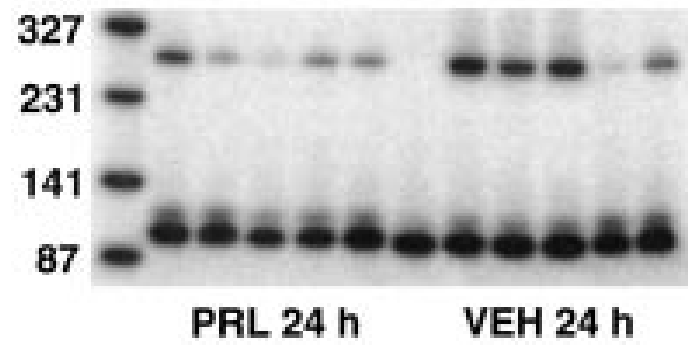

\section{PRL-R 279 \\ S16 100}

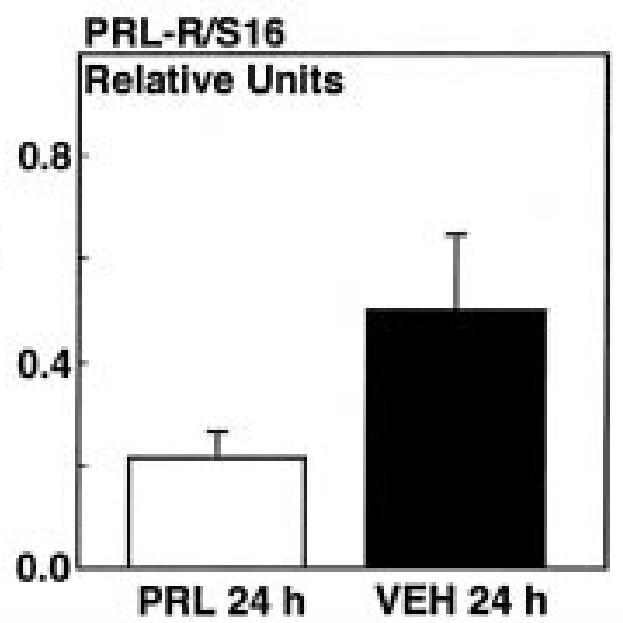

Figure 3 Expression of mRNA for prolactin receptor (PRL-R) long form (top) and short form (bottom) for corpora lutea of prolactintreated (PRL; lanes 2-6) and vehicle-treated (VEH; lanes 8-12) rats at $24 \mathrm{~h}$ after the onset of treatment. The PCR reaction product for both forms of the PRL-R runs at $279 \mathrm{bp}$, while the internal control, S16, runs at $100 \mathrm{bp}$. Each lane contains cDNA derived from corpora lutea of one rat. Lane 7 contains cDNA from the GGCL cell line, a negative control for PRL-R. The times of exposure are identical for the two autoradiograms. Results from each autoradiogram are shown graphically on the right-hand side, as PRL-R/S16 expressed as relative densitometric units.

least part of this luteotrophic action of prolactin appears to be transmitted through the long form of the prolactin receptor $(25,26)$. The short form of the prolactin receptor may signal through a different pathway than the long form in the rat corpus luteum; certainly it appears to have some different protein associations in this tissue (22). An intriguing hypothesis, therefore, was that the short form of the prolactin receptor, acting through an independent signalling pathway, was responsible for the luteolytic actions of prolactin. We proposed that, if this were the case, the short form of the prolactin receptor would be dominant in corpora lutea of the hypophysectomized rat, which are able to respond to prolactin with luteal regression, and that prolactin would act to upregulate this form of the prolactin receptor. Our results do not support this proposal, as the long form of the prolactin receptor is still dominant in these corpora lutea, as it is during pregnancy, and there is no clear upregulation of the short form of the prolactin receptor. However, we do observe some interesting changes in the expression of mRNA for the two forms of the prolactin receptor, once prolactin-induced luteal regression has been initiated.

Prolactin treatment causes an increase in abundance of mRNA for the long form of the prolactin receptor when it is acting as a luteotrophin, during pregnancy (24). The short form does not appear to be affected, resulting in an alteration in the ratio of the short to the long form of the prolactin receptor. During prolactininduced luteolysis, as examined in the current study, 


\section{Prolactin Receptor Long Form}
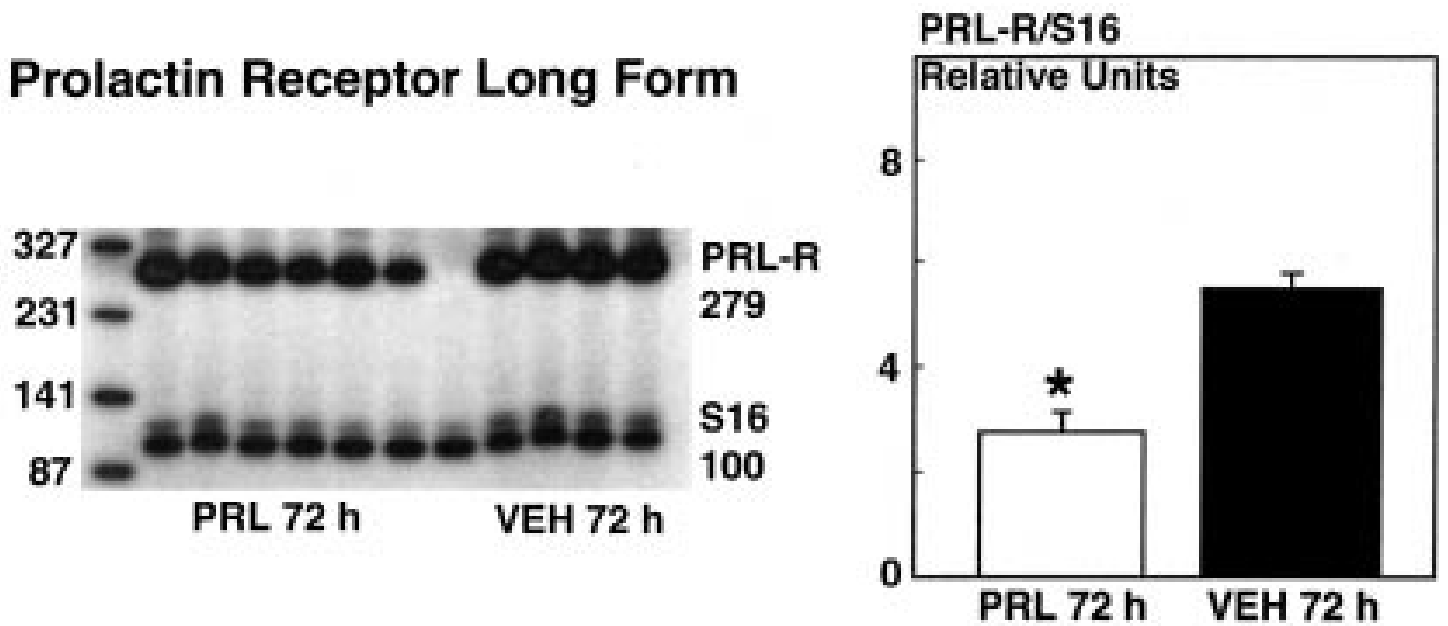

\section{Prolactin Receptor Short Form}
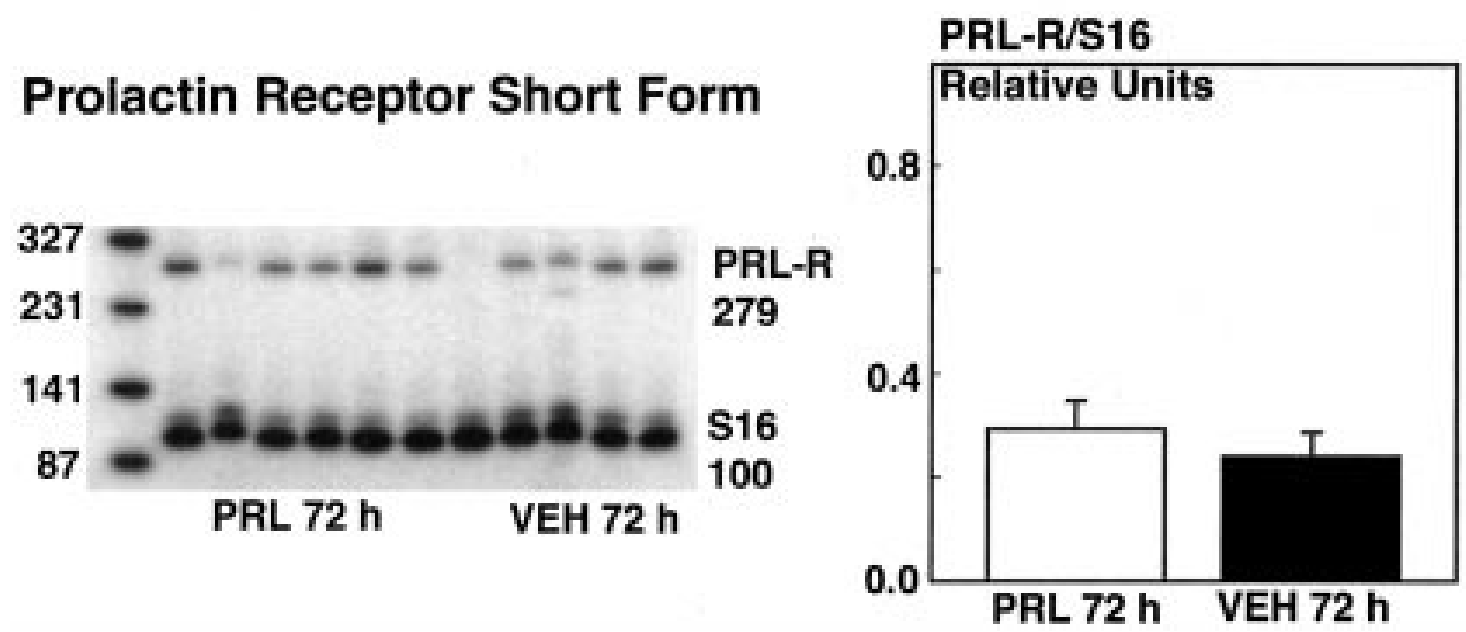

Figure 4 Expression of mRNA for prolactin receptor (PRL-R) long form (top) and short form (bottom) for corpora lutea of prolactintreated (PRL; lanes 2-7) and vehicle-treated (VEH; lanes 9-12) rats at $72 \mathrm{~h}$ after the onset of treatment. The PCR reaction product for both forms of the PRL-R runs at $279 \mathrm{bp}$, while the internal control, S16, runs at $100 \mathrm{bp}$. Each PRL lane contains cDNA from corpora lutea of two to three rats, while each VEH lane contains CDNA from corpora lutea of one rat. Lane 8 contains cDNA from the GGCL cell line, a negative control for PRL-R. The times of exposure are identical for the two autoradiograms. Results from each autoradiogram are shown graphically on the right-hand side, as PRL-R/S16 expressed as relative densitometric units. The asterisk indicates a significant difference at $P<0.01$.

there also appears to be an alteration in this ratio. However, the alteration in this case is in the inverse direction of the alteration during the luteotrophic action of prolactin. The ratio between the long and short forms of the prolactin receptor has been previously shown to be an important parameter in determining response to prolactin in different tissue types (30), and changes in this ratio may help to explain how prolactin is able to carry out both luteotrophic and luteolytic actions in the corpus luteum. Alteration in the ratio of the receptor isoforms is, however, insufficient to explain the ability of prolactin to induce luteal regression in the hypophysectomized rat, since this change in ratio appears to occur only after prolactin-induced luteal regression has been initiated.

The conversion of the corpus luteum to a tissue which is able to respond luteolytically to prolactin begins with the removal of prolactin. This conversion apparently takes 3 days to complete, as prolactin is able to act as a luteolysin only 3 or more days after hypophysectomy $(1,2)$. The exact changes in the corpus luteum are unknown; however, they may include alterations in the signalling pathways coupled to the prolactin receptor. These alterations may consist of changes in specific transcription factors or other key proteins in these pathways. The overall result appears to be a restructuring of the signalling pathways linked to the prolactin receptors such that restored prolactin acts as a luteolysin. The apparent change in ratio of short form to long form prolactin receptor observed in this study appears to be initiated as part of the luteolytic action of 
prolactin, and may play a part in maintaining the luteolytic response of the tissue, once it has been initiated. The means by which prolactin can execute both luteotrophic and luteolytic responses in the rat corpus luteum remains an intriguing subject for further investigation. In particular, elaboration of the signalling pathways linked to the prolactin receptor isoforms in these two systems is required.

\section{Acknowledgements}

Ovine prolactin was donated by the National Hormone and Pituitary Program, National Institute of Diabetes and Digestive and Kidney Diseases, the National Institute of Child Health and Human Development, and the US Department of Agriculture. We are grateful to S Kitzsteiner of the Chemistry Core Facility of the Michigan Diabetes Research and Training Center for radioimmunoassays, S Ferguson and Dr G Gibori for assistance with RT-PCR, and the P30 Assay and Reagents Core of the Reproductive Sciences Program, University of Michigan for assay reagents. This work was supported by NIH HD-33478 (PLK) and FIC 1F05TW05241 (CMT). Support was also provided by the Assays and Reagents Core Facility of the P30 Center for the Study of Reproduction (NIH HD-18258). This work was presented in preliminary form at the 31st Annual Meeting of the Society for the Study of Reproduction in College Station, TX, USA in 1998.

\section{References}

1 Malven PV. Luteotrophic and luteolytic responses to prolactin in hypophysectomized rats. Endocrinology 196984 1224-1229.

2 Malven PV \& Sawyer CH. A luteolytic action of prolactin in hypophysectomized rats. Endocrinology 196679 268-274.

3 Taya K \& Greenwald GS. In vivo and in vitro ovarian steroidogenesis in the long term hypophysectomized rat. Endocrinology $1982110390-397$.

4 Bowen JM, Keyes PL, Warren JS \& Townson DH. Prolactininduced regression of the rat corpus luteum: expression of monocyte chemoattractant protein-1 and invasion of macrophages. Biology of Reproduction 199654 1120-1127 (published erratum appears in Biology of Reproduction 199655 224).

5 Townson DH, Remick DG, Warren JS \& Keyes PL. The effect of dexamethasone (DEX) on prolactin-induced monocyte chemoattractant protein-1 (MCP-1) expression and macrophage infiltration in regressing corpora lutea of the rat. Biology of Reproduction (Suppl) 199654145 (Abstract no. 354).

6 Albarracin CT, Parmer TG, Duan WR, Nelson SE \& Gibori G. Identification of a major prolactin-regulated protein as $20 \alpha$ hydroxysteroid dehydrogenase: coordinate regulation of its activity, protein content, and messenger ribonucleic acid expression. Endocrinology 1994134 2453-2460.

7 Richards JS, Ireland JJ, Rao MC, Bernath GA, Midgley AR Jr \& Reichert LE Jr. Ovarian follicular development in the rat: hormone receptor regulation by estradiol, follicle stimulating hormone and luteinizing hormone. Endocrinology 197699 1562-1570.

8 Gibori G. The corpus luteum of pregnancy. In The Ovary, pp 261-317. Eds EY Adashi \& PCK Leung. New York: Raven Press, 1993.

9 Albarracin CT, Palfrey HC, Duan WR, Rao MC \& Gibori G. Prolactin regulation of the $\mathrm{Ca}^{2+} /$ calmodulin-dependent protein kinase III-elongation factor 2 system in the rat corpus luteum. Journal of Biological Chemistry 1994269 7772-7776.

10 Kelly PA, Ali S, Rozakis L, Goujon L, Nagano M, Pellegrini I et al. The growth hormone/prolactin receptor family. Recent Progress in Hormone Research 199348 123-164.

11 Lesueur L, Edery M, Ali S, Paly J, Kelly PA \& Djiane J. Comparison of long and short forms of the prolactin receptor on prolactininduced milk protein gene transcription. PNAS 199188 824828 .

12 Edery M, Levi-Meyrueis C, Paly J, Kelly PA \& Djiane J. A limited cytoplasmic region of the prolactin receptor critical for signal transduction. Molecular and Cellular Endocrinology 1994102 39-44.

13 Das R \& Vonderhaar BK. Transduction of prolactin's (PRL) growth signal through both long and short forms of the PRL receptor. Molecular Endocrinology 19959 1750-1759.

14 Gouilleux F, Wakao H, Mundt M \& Groner B. Prolactin induces phosphorylation of Tyr694 of Stat 5 (MGF), a prerequisite for DNA binding and induction of transcription. EMBO Journal 199413 4361-4369.

15 Ball R, Friis R, Schoenenberger CA, Doppler W \& Groner B. Prolactin regulation of casein expression and of a cytosolic 120$\mathrm{kd}$ protein in a clone mouse mammary epithelial cell line. PNAS $198886104-108$.

16 Li S \& Rosen JM. CTF/NFI and mammary gland factor (Stat 5) play a critical role in regulating rat whey acidic protein gene expression in transgenic mice. Molecular Cell Biology 199515 2063-2070.

17 Lebrun J-J, Ali S, Sofer L, Ullrich A \& Kelly PA. Prolactin-induced proliferation of $\mathrm{Nb} 2$ cells involves tyrosine phosphorylation of the prolactin receptor and its associated tyrosine kinase JAK2. Journal of Biological Chemistry 1994269 14021-14026.

18 Rui H, Kirken RA \& Farrar WL. Activation of receptor-associated tyrosine kinase JAK2 by prolactin. Journal of Biological Chemistry $19942695364-5368$.

19 Dusanter-Fourt I, Muller O, Ziemiecki A, Mayeux P, Drucker B, Djiane J et al. Identification of JAK protein kinases as signaling molecules for prolactin. Functional analysis of prolactin receptor chimera expressed in lymphoid cells. EMBO Journal 199413 2583-2591.

20 Lebrun J-J, Ali S, Ullrich A \& Kelly PA. Proline-rich sequencemediated Jak2 association to the prolactin receptor is required but not sufficient for signal transduction. Journal of Biological Chemistry $199527010664-10670$.

21 Chang W-P \& Clevenger CV. Modulation of growth factor receptor function by isoform heterodimerization. PNAS 199693 59475952.

22 Duan RW, Linzer DIH \& Gibori G. Cloning and characterization of an ovarian specific protein that associates with the short form of the prolactin receptor. Journal of Biological Chemistry 1996271 15602-15607.

23 Nokelain P, Peltoketo H, Vihko R \& Vihko P. Expression cloning of a novel estrogenic mouse 17 hydroxysteroid dehydrogenase/17ketosteroid reductase (m17HSD7), previously described as a prolactin receptor-associated protein (PRAP) in rat. Molecular Endocrinology $1998121048-1059$.

24 Telleria CM, Parmer TG, Zhong L, Clarke DL, Albarracin CT, Duan WR et al. The different forms of the prolactin receptor in the rat corpus luteum: developmental expression and hormonal regulation in pregnancy. Endocrinology $19971384812-4820$.

25 Russell DL, Normal RL, Dajee M, Liu X, Henninghausen L \& Richards JS. Prolactin induced activation and binding of Stat proteins to the IL-6RE of the $\alpha 2$-macroglobulin $(\alpha 2 \mathrm{M})$ promotor: relation to the expression of $\alpha 2 \mathrm{M}$ in the rat ovary. Biology of Reproduction 199655 1029-1038.

26 Ruff SJ, Leers-Sucheta S, Melner MH \& Cohen S. Induction and activation of Stat 5 in the ovaries of pseudopregnant rats. Endocrinology $19961374095-4099$.

27 Bender EM, Miller JB, Possley RM \& Keyes PL. Steroidogenic effect of $17 \beta$-estradiol in the rabbit: stimulation of progesterone 
synthesis in prematurely regressing corpora lutea. Endocrinology 1978103 1937-1943.

28 Sugino N, Zilberstein M, Srivasta RK, Telleria CM, Nelson SE, Risk $\mathrm{M}$ et al. Establishment and characterization of a simian virus 40-transformed temperature-sensitive rat luteal cell line. Endocrinology 1998139 1936-1942.

29 Zhang R, Buczko E, Tsai-Morris CH, Hu ZZ \& Dufau ML. Isolation and characterization of two novel rat ovarian lactogen receptor cDNA species. Biochemical and Biophysical Research Communications $1990168415-422$.
30 Jahn GA, Daniel N, Jolivet G, Belair L, Bole-Feysot C, Kelly PA \& Djiane J. In vivo study of prolactin (PRL) intracellular signaling during lactogenesis in the rat: JAK/STAT pathway is activated by PRL in the mammary gland but not in the liver. Biology of Reproduction 199757 894-900.

Received 16 September 1999

Accepted 5 April 2000 